Electronic Journal of Research

\title{
Understanding adolescents' moral stance on examination malpractice through the lenses of parenting styles, test anxiety, and their academic self-efficacy
}

\section{Kingsley Chinaza Nwosu ${ }^{1}$, Victor Chekume Nwasor ${ }^{1}$, Geoffrey C. Onyebuchi ${ }^{1}$, Victor C. Nwanguma ${ }^{2}$}

${ }^{1}$ Department Educational Foundations, Nnamdi Azikiwe University, Awka

${ }^{2}$ Alvan Ikoku College of Education, Owerri

Nigeria

Correspondencia: Kingsley Chinaza Nwosu, PhD, Educational Foundations, Nnamdi Azikiwe University, Awka, PMB 5025. E-mail: kc.nwosu@unizik.edu.ng

(C) Universidad de Almería and Ilustre Colegio Oficial de la Psicología de Andalucía Oriental (Spain) 


\begin{abstract}
Introduction. The increasing complex nature of academic dishonesty demands that empirical models are built to explain the psychosocial and motivational variables involved in the way examination malpractice is morally viewed by adolescents. This has been underexplored in Nigeria over the years given that available studies have not utilized designs that could give comprehensive understanding of pathways through which moral views of adolescents on examination malpractice could be predicted.
\end{abstract}

Method. This study developed an empirical model using path analysis to explain the direct and indirect effects of parenting styles, test anxiety, academic self-efficacy on adolescents' moral stance on examination malpractice scenarios. The multivariate predictor correlational research design was adopted. Dimensions of the parenting styles served as exogeneous variables while test anxiety, self-efficacy and moral stance on examination malpractice served as endogeneous variables with test anxiety and self-efficay serving as mediators. The sample size was made up of 741 senior seconday school students, classs one (SS1) from 15 secondary schools located in southeast geopolitical zone of Nigeria.

Results. Findings showed, among others, that the final hypothesized model fit the data satisfactorily and that permissive parenting style and test anxiety significantly and positively predicted adolescents' amoral stance on examination malpractice while authoritative parenting negatively predicted their amoral stance on examination malpractice. Permissive parenting style had both direct and indirect significant effects on adolescents' moral stance on examination malpractice.

Discussion and Conclusion. Discussion was based on the findings resulting to the conclusión that inappropriate parenting style and problematic psychological dispositions are factors that could influence the moral views of adolescents. For appropriate intervention to be mounted for students, there is the need to incorporate how adolescents are trained by their parents.

Keywords: parenting styles, test anxiety, academic self-efficacy, examination malpractice, morality 


\section{Resumen}

Introducción. La creciente naturaleza compleja de la deshonestidad académica exige que los modelos empíricos se construyan para explicar las variables psicosociales y motivacionales involucradas en la forma en que los adolescentes consideran moralmente la mala práctica del examen. Esto ha sido poco explorado en Nigeria a lo largo de los años, dado que los estudios disponibles no han utilizado diseños que puedan proporcionar una comprensión integral de las vías a través de las cuales se podrían predecir los puntos de vista morales de los adolescentes sobre la mala práctica del examen.

Método. Este estudio desarrolló un modelo empírico que utiliza el análisis de ruta para explicar los efectos directos e indirectos de los estilos parentales, la ansiedad ante los exámenes, la autoeficacia académica en la postura moral de los adolescentes en los escenarios de mala práctica en los exámenes. Se adoptó el diseño de investigación correlacional predictivo multivariante. Las dimensiones de los estilos de crianza sirvieron como variables exógenas, mientras que la ansiedad ante los exámenes, la autoeficacia y la postura moral sobre la mala práctica del examen sirvieron como variables endógenas en la ansiedad ante los exámenes y la autoeficacia como mediadores. El tamaño de la muestra estaba compuesto por 741 estudiantes de SS1 de 15 escuelas secundarias ubicadas en la zona geopolítica sureste de Nigeria.

Resultados. Los hallazgos mostraron, entre otros, que el modelo hipotético final se ajustaba satisfactoriamente a los datos y que el estilo de crianza permisivo y la ansiedad de prueba predijeron significativamente y positivamente la postura amoral de los adolescentes en la mala práctica del examen, mientras que la crianza autoritaria predijo negativamente su postura amoral en la mala práctica del examen. El estilo de crianza permisivo tuvo efectos significativos tanto directos como indirectos en la postura moral de los adolescentes sobre la mala práctica del examen.

Discusión y conclusión. La discusión se basó en los hallazgos resultantes de la conclusión de que el estilo de crianza inapropiado y las disposiciones psicológicas problemáticas son factores que podrían influir en las opiniones morales de los adolescentes. Para que se desarrolle una intervención apropiada para los estudiantes, existe la necesidad de incorporar cómo los padres capacitan a los adolescentes.

Palabras clave: estilos parentales, ansiedad ante los exámenes, autoeficacia académica, mala práctica de examen, moralidad. 


\section{Introduction}

Studies in Nigeria and beyond have provided insights into causes and forms of examination malpractices (Alhassan \& Anya, 2017; Anzene, 2014; Paul, Wada, Audu, \& Omisore, 2013). Yet an understanding of the relationships between psychosocial factors (parenting styles, test anxiety and academic self-efficacy) and adolescents' moral stance on examination malpractice and how these variables interact to impact on adolescents' moral stance on examination malpractice scenarios seems to be underexplored. Granted is the fact that one major impediment to measure the quality of education received by students is examination malpractice (Nwosu, Nwasor, \& Nezieanya, 2018). This has put stakeholders on tenterhooks considering the fact that it renders certification incapable of representing proficiency. It has been seen as one of the greatest problems undermining the foundations of educational practice (Naliaka, Odera, \& Poipoi, 2015). The impact of examination malpractice is enormous in the educational system of any nation. Nwosu et al. (2018) have noted that examination malpractice in the Nigerian context looks insurmountable going by its redefinition by perpetrators that appears to have eroded its characteristic illegality.

Studies have been carried out on the forms of examination malpractice in Nigerian schools (Alhassan \& Anya, 2017). These forms are subtly presented or even coded that it appears examination malpractice has no inherent danger on the educational system; and these have been nicknamed 'expo, giraffing, lateral connection, dubbing, contract, tattoo, rank Xeroxing, computo, missile catch, swapping, token, body aids, mercenary services, table top, CNN, time out, direct access, stroke and e-cheating' (Alhassan et al., 2017). Examination malpractices are supported by significant persons in the society including parents, teachers, personnel of examination bodies, and security agencies. In public examinations, officially reported cases of examination malpractices have been increasingly alarming (Anzene, 2014; Paul et al., 2013). Four key factors have been identified in examination malpractices which are the generators (students/candidates taking the examination), the facilitators (administrators/examiners), the indicators (written and unwritten exhibits), the detectors (the few individuals with integrity) (Ifijeh, Michael-Onuoha, Ilogho, \& Osinulu, 2015). Casual factors of examination malpractices have been summarized as society-related factors, institution-related factors, teacher-related factors, learner-related factors and group-related factors (Alhassan et al., 2017). 
A lot of reasons have been adduced for students to engage in examination malpractice. These include unpreparedness for exams, overemphasis on certification, inability to cover the content of the test, poor study habits, lack of confidence, family pressure (Naliaka et al., 2015, Peters \& Okon, 2014). One common denominator across the findings of different scholars is the fact that pressure from significant persons (parents and peers) and psychological disposition (self-belief systems and test anxiety) of students play important part in students' participation in examination malpractices. Researchers have established that relationship exists between parental factors and students' involvement in examination malpractice (Animasahun \& Ogunniran, 2014), parenting style and students' attitude to examination malpractices (Onyekuru \& Kabari, 2017), parental motivation and academic dishonesty (Okorodudu, 2012).

In the process of nurturing the child, parents impart a kind of value system on them. Behavioural tendencies are reinforced by principles held in life over a time. These guiding principles which serve as yardsticks to select, justify, and evaluate actions, people and events are regarded as values (Knafo \& Schwartz, 2003). Parental values are transmitted to children through socialization enabling such children to remain in the parental stratum during adulthood (Wright \& Wright, 1976). Recent studies have shown that such transmissions are a bidirectional course which allows active processing of information especially among adolescents in which they may accept or reject projected parental values (Barni, Ranieri, Scabini, \& Rosenati, 2011). Within this broad conceptualization of parental value and value transmission is located the direction of priority given to issues of life by parents. Taskinen, Dietrich, and Kracke (2014) in their study established that there is a significant relationship between parental values and students' motivation and achievement. Research has shown that students are involved in cheating in examination when they consider their grade to be more important to their parents than they themselves thereby are more likely to cheat to impress their parents (Holleque, 1982). The value system could be influenced by the kind of parenting style adopted or even directed by the kind of parenting styles adopted by parents.

Parenting styles are seen as an assortment of specific, goal-directed and non-goal directed behaviours of parents that represent the channels through which parents perform their duties (Darling \& Steinberg, 1993). Darling and Steinberg are of the view that the sum total of these behaviours communicated to children forms an emotional climate for the expression of parents' behaviours and consists of three major components which include: 'the emotional 
relationship between the parent and child, the parents' practices and behaviors, and the parents' belief systems' (p.488). Parenting styles can equally be a reflection of all-embracing parenting dimensions representative of clusters/factors of related parenting practices (Kuppens \& Ceulemans, 2018). The views of Kuppens and Ceulemans (2018) were a recognition of the efforts to disambiguate parenting styles and practices.

Parenting practices tend to be more context specific parent-child interactions while parenting styles encompass a general pattern of belief, behavior, and attitudes of the parent towards the child (Darling \& Steinberg, 1993). Amos (2013) has it that these parental practices have their chronological exgencies as some are age appropriate, and border on conditioning offspring to behave in ways that are acceptable to society using sanctions and sundry reinforcements to either encourage or discourage the behaviours that highlight acquired values. Such parental/child rearing practices include, but are not limited to the oral transmission of what is acceptable and what is taboo, initiatoin through rites of passage into groups that are important to community jurisprudence (In Igbo land, this will be the mmanwu societies), praise for good behaviour and repercussion for bad behaviour.

Parenting styles have been conceptualized to include authoritarian, authoritative and permissive parenting (Bacus, 2014; Kuppens \& Ceulemans, 2018). Authoritarian parenting style depicts a parenting climate that demands unquestionable submission to parents' demands while parents show a high degree of strictness without much emotional attachment; permissiveness is a connotation of lax parental restrictions and guidiance while authoritative parenting style is a resemblance of democratic parenting in which parenting involves very clear and firm direction to children (Bacus, 2014). Authoritative parents while consistently providing emotional support and positive reinforcement place high positive demands on children; authoritarian parents without much emotional supports and reniforcements are high in negative demands while permissive parents show little demandingness but are highly responsive (Bednar and Fisher, 2003, Sullivanet al., 2010 as cited in Cameron, Cramer, \& Manning, 2018). Ajiboye, Atere and Olufunmi (n.d) posited that in multicultural societies like Nigeria, cultural beliefs have led to a widespread adoption of authoritarian parenting styles with the resultant effect of having children who grow up lacking self-efficacy, self-esteem and the confidence to thrive outside their homes. Nwosu, et al have noted that the Nigerian cultural peculiarity which is largely hierarchical has enthroned parenting style trajectories that revolve around the "authoritarian/authoritative parenting, and the authoritative parenting styles" 
(p.33). In this culture, children are most of the time expected to religiously adhere to the rules and regulations in the family without questioning. In addition, Ajiboye et al. (n.d) noted that children of parents with authoritative parenting styles tend to be more socially adept and selfconfident. This stems from the fact that authoritative parenting environment offers the opportunity for meaningful parental support to the child. Conversely, children from homes where the parents are neglectful/permissive tend to be emotionally immature and engage in behaviours that are socially abhorrent. It suffices to imply that students whose parents are authoritarian might likely have a low moral stance on examination malpractice because since their parents seldom listen to their own side of the story, they choose to have performance orientations than mastery academic goal orientations. This can lead to examination malpractice in order for parents to render elusive praise on them and make them feel accepted, while inwardly aware that they are undeserving of accolades for their nefarious act.

Furthermore, psychological dispositdion of the child could prompt indulgence in examination malpractices. Attempts have been made by researchers to investigate relationship existing between students' psychological dispositions and their indulgence and/or the tendency to indulge in examination malpractice. One of such psychological constructs that have influence on students' academic performances is test anxiety. Research has shown that students who are not anxious about their social evaluations are not likely to indulge in examination malpractice (Wowra, 2007). Test anxiety has the capacity to obstruct cognitive functioning, which can push a student into indulging in examination malpractices more especially when the child perceives impeding failure in a particular test. Another important psychological factor in academic performance of the child is the academic self-efficacy rooted in Albert Bandura's Social Cognitive Theory. Having self confidence in one's academic ability is likely to ameliorate engagement in academic dishonesty (Animasahun, et al., 2014; Jurdy, Hage, \& Chow, 2011; Nora \& Zhang, 2010).

The Nigerian educational system for over the years has been bedevilled by increasing incidence of examination malpractice that the situation has reached a level that there is now a 'deadly combination of campus cultism, sex-for-grades and money-for-grades epidemics' which is a 'ticking time bomb in the belly of education that require urgent intervention of marshal plan proportions to diffuse' (Exam Ethics Marshals International, 2019). Exam Ethics Marshals International (2019) in their 20-point marshal plan for the eradication of examination malpractice in Nigeria noted that 'there are 47 distinct types of examination and academ- 
ic malpractices and dishonesty that are now prevalent in education from primary to secondary to tertiary levels' and that 'exam malpractice syndicates device new methods, especially through electronic devices, to compromise each exam circle [sic] as exam bodies introduce measures to check old tricks'. Students from primary and tertiary institutions are directly or indirectly involved in examination malpractice. Despite the efforts made by concerned stakeholders to eradicate the menace, each examination cycle is marred by reported cases of examination misconduct. Investigation into casual factors that have facilitated indulgence in examination malpractices becomes pertinent.

Studies in the Nigerian context that examined relationship between psychosocial variables and examination malpractices did so looking at individual variable correlations and provided a separate explanation ratio for each variable. There has not been an attempt to adopt more robust statistical analysis to understand associations among such variables while at the same time providing explanation ratios of these relationships to each other. The need to understand the relationships, predictive ability and direct impact of parenting styles, test anxiety, academic self-efficacy and moral stance of students on examination malpractices becomes pertinent given the increasing rate of academic dishonesty among students in Nigeria. This will help develop a model that could be used in explaining students' moral stance on examination malpractice and as well help in mounting intervention programmes that could prevent indulgence in examination malpractice. Researchers are of the view that to decrease antisociality among adolescents, attention must be focused on their parenting styles which fuels their belief systems and dispositions (Johnson, 2016). Such belief systems and dispositions which include their evaluation of their abilities and situations could include adolescents' academic self-efficacy and test anxiety.

\section{Parenting styles and examination malpractice}

Formation of values begins at the home. These values are nurtured by parents whose responsibilities it is to direct their wards to become responsible children in the larger society. In doing these mechanisms are adopted to put this across. The patterns of parenting which parents adopt to inculcate values in their children are referred to as parenting styles. These patterns may depict the directions of the values of parents and the conviction of the best way to train their children. Implicit in the parenting style is the pathways through which the child approaches issues including engagement in examination malpractices. In the case of examination malpractice, parents have been indicted to encouraging examination malpractices in 
schools through their threat to supervisors, pressure on their wards to secure high marks, encouraging their children to indulge in examination malpractice, unnecessary care for supervisors (Suleman, Gul, Ambrin, \& Kamran, 2015). Studies in Nigeria have failed to exonerate parents in the unholy practice of examination malpractice (Ojo \& Olumuyiwa, 2011). In their study, they found that parents go as far as taking their wards to 'special centers' where examination malpractices take place in an alarming proportion. And what makes these centers 'special' is the fact that these students' are offered protection to engage in examination malpractice having paid mercenaries for the examinations. In studies establishing relationships between parenting styles and examination malpractices, permissive parenting had strong positive significant relationship with examination malpractice tendencies (Opiyo, Aloka, Raburu, $\&$ Aomo, 2018). There is the likelihood that a child will see nothing wrong in examination malpractice if he/she sees parents being in support and sponsoring of examination malpractice.

\section{Test anxiety and examination malpractice}

Test anxiety emerges when tests are seen as threat instead of prognostic, predictive and remedial measures (Nwosu, Odo, \& Obioha, 2017). This is worsened in case scenarios in which passing examinations is seen as major gateway to success in life. In such situations there could be heightened emotions that lead to examination malpractice. Research has shown that test anxiety is negatively significantly related to students' successes in examinations and stands as one of the factors that lead to underachievement in schools (Rana \& Mahmood, 2010). Cassady (2004) has noted that test anxiety has the capacity to impair retrieval, storage and processing mechanism in human memory. When this occurs, there is the likelihood that such individual may engage in examination malpractice as a defensive mechanism (Nwosu, et al, 2017). Studies show that lack of confidence which is related to test anxiety is associated to examination malpractice (Naliaka, et al, 2015), test anxiety is significantly positively related to students' tendency to participate in examination malpractice (Nwosu, et al, 2017), and students' attitude towards examination malpractice (Ossai, 2011). Students' perception on examination malpractice could be affected by their level of text anxiety going by distortion it could cause in the working memory during examinations.

\section{Self-efficacy and examination malpractice}

Self-efficacy is another psychological variable that its relationship with examination malpractice has been studied. This could have been informed by the possibility that those who 
are confident in their abilities are likely not to engage in examination malpractice. Ofodile, Odiato, Adenugba, and Edun (2019) in their study, established that there was significant negative relationship between secondary school students' self-efficacy and their engagement in examination malpractice. This is possible given the fact that students who belief that they are capable of tackling a task, are also likely to resist the temptation to indulge in examination malpractices. Cornelius-Ukpepi, Ndifon, and Enukoha (2012) noted that self-efficacy is a correlate of examination malpractice and argued that it is one of the mechanisms that is involved in self-regulation of one's behaviour. They went further to investigate the relationships existing among the correlates of examination malpractice such as self-efficacy and moral tone of schools, and the academic achievement of students in which they concluded that high selfefficacy of students could help them tackle indulgence in examination malpractice.

\section{Objectives and Hypotheses}

Going by available literature, this study set out to fit the conceptual model in which students' parenting styles, academic self efficacy and test anxiety explain their moral stance on examination malpractice. It also aimed at determining the direct and indirect effects of the exogenous variables on the endogenous variables. Therefore, we hypothesized that:

a. The data will not significantly fit the conceptual model.

b. The parenting styles will not significantly have direct effects on academic selfefficacy, test anxiety and moral stance on examination malpractice

c. Test anxiety and academic self-efficacy significantly mediates the relationship between parenting styles and moral stance on examination malpractice.

\section{Method}

\section{Participants}

The sample size consisted of 741 SS1 students during the 2017/2018 academic session in 15 secondary schools located in southeast geopolitical zone of Nigeria. The researchers randomly sampled three out of five states in southeast (Abia, Anambra, Ebonyi, Enugu and Imo States). Five public owned secondary schools were randomly sampled from each of the three states in which 50 students were randomly sampled given a total of 750 students. However, only 741 students completed the filling in of the questionnaire. These states predominately constitute the Igbo people of Nigeria, while Igbo people can be found in nongeographically designated regions such as Delta and Rivers States. The choice of the area of 
study was predicated on the premise that 48 secondary schools were derecognized by the Federal Government of Nigeria from 2007 to 2010 (Anzene, 2014, see also as cited by Nwosu, et al, 2018) as result of their involvement in examination malpractice, and Nwosu et al. (2018) have found that more than $38 \%$ of secondary school students in this area see nothing wrong in violating examination ethics before, during and after examinations.

\section{Instruments}

Four instruments were used in the study. The parenting authority questionnaire (PAQ) developed by Buri (1991) was used in determining students' parenting styles. This instrument contained 30 items of three subscales of permissive parenting (items 1, 6, 10, 13, 14, 17, 19, 21, 24 and 28), authoritarian parenting (items 2, 3, 7, 9, 12, 16, 18, 25, 26 and 29) and authoritative parenting (items 4, 5, 8, 11, 15, 20, 22, 23, 27, and 30). These items are scaled from strongly agree to strongly disagree. The internal consistencies of the items in the three subscales in the present study were determined using Cronbach Alpha and the coefficents for permissive, authoritarian and authoritative parenting styles were $.67, .61$ and .60 respectively. For the determination of students' test anxiety scores, the Test Anxiety Inventory (TAI) developed by Spielberger (1980) was used. The inventory was intended for secondary school students and undergraduate students, and consists of 20 items which are short, self-descriptive statements scaled from 1 for "Anxiety almost never" to 4 for "almost always". Oladimeji (2005) has reported the psychometric properties of the test anxiety scale which were determined using Nigerian students. He stated that the scale has good psychometric indices. In the present study, the reliability coefficient using Cronbach Alpha test was .88.

The self-efficacy questionnaire for children (SEQ-C) developed by Muris (2001) for secondary school students was used to measure students' academic self-efficacy. Only the academic self-efficacy cluster was used in the present study though the questionnaire contained 3 clusters of academic, emotional and social self-efficacy. The brief survey questionnaire contains 24 items of 8 items for each of the three sub-scales. Items were structured on 5 point scale of 'not at all' to 'very well'. A total academic self-efficacy score can be obtained by summing the 8 items. The reliability coefficients was .80 using Cronbach Alpha test.

To determine students' moral stance on examination malpractice, the Student Moral Stance on Examination Malpractice Questionnaire (SMSEMQ), a 25-item questionnaire developed by Nwosu, et al (2018) structured in the four-point scale of strongly agree (SA), 
agree (A), disagree (D) and strongly disagree (SD) was used in collecting the data. Nwosu, et al (2018) reported that the instrument was developed after an extensive literature review including the consultation of the work of Bisong, Akpama, and Edet (2009). It involved the presentation of examination malpractice case scenarios in which students were required to either agree or disagree to whether it was right to indulge in them. These scenarios are dominant contemporary forms of examination malpractice in Nigeria. Higher scores in the questionnaire indicate that the respondent sees nothing wrong with the case scenarios. From the scores, the moral stance of the student regarding the case scenario is inferred. The questionnaire was structured in such a way that higher scores shows that the respondent has negative moral stance on examination malpractice. Examples of items are 'I don't think it is wrong to see the question paper before the examination', 'If I have the opportunity to bribe a teacher to tell me the answers to questions to examination I will do that', 'It is not wrong to peep from my mate's work during examination', 'It is not wrong to exchange ideas in examination hall with my colleagues', 'It is not wrong writing some formula in my hand/laps before entering the hall, as reminder', 'It is not wrong to ask teachers for an answer in examination hall', 'It is not wrong for one to copy answers written on the board by teachers' etc. The reliability of the instrument using Cronbach Alpha test was .95.

\section{Procedure}

The design of the study is the multivariate predictor correlational research design. Path analysis was adopted to analyze the predictive powers of the exogenous variables on the endogenous variables as well as determining how two endogenous variables mediated the relationship existing among parenting styles and students' moral stances on examination malpractice scenarios. This path model is conceptualized on sociocultural/dialogical theories of morality in which moral functioning is 'mediated by social, cultural, historical context' (Tappan, 1997, as cited in Tappan, 2005 p. 345) and subsists in inner and private speech (Tappan, 2005). Since the child's development begins from the family and extends to the larger society, his moral development is likely to be influenced by the kind of parenting style adopted in bringing the child up. We also conceptualized that students' academic self-efficacy and test anxiety could mediate the impact parenting styles could have on their moral stance on examination malpractice. However, initial conceptualization did not fit the data, but when the path from permissive parenting to self-efficacy was removed the data fit the model perfectly. The final conceptualized model is presented in figure 1. 


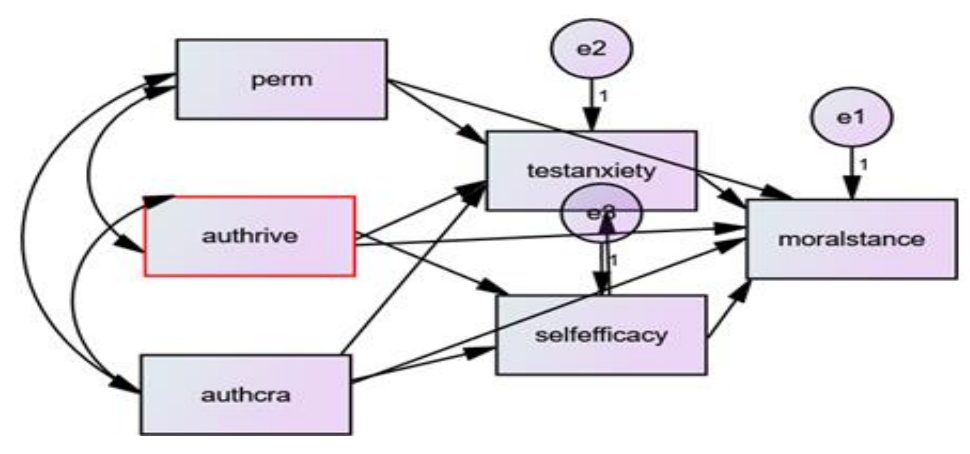

Figure 1. Final Conceptual model showing the relationships existing among the variables

Before the administration of the instruments, a consent letter was sent to the school authorities and the purpose of the study was explained to them. When they consented, the classroom teachers served as research assistants and helped in explaining the purpose of the study to the students. Students were told that the study was not mandatory, that any student could opt out of the study. The instruments were filled in on the spot and the teachers retrieved them form the students. Nine students opted out of the study.

\section{Datal Analysis}

Before the main analysis, assumptions were tested. First the sample size was taken into consideration before running path analysis. Our hypothesized model had 20 distinct parameters with a sample size of 741 amounting to a ratio of 37:1 which falls within the acceptable range as propounded by Kline (2011). Kline (2011) had recommended that the ratio of the sample size-to-parameter be estimated at 10:1, in spite of the fact that a more ideal sample size-to-parameter estimate would be 20:1.

Missing values were handled using regression imputation in Amos. Regression imputation takes into account 'subjects patterns of scores across all other variables' and predict 'a score for each subject by using multiple regression based on their non-missing scores for other variables' (Carter, 2006). The essence of this is to preserve the relationship between the variables since imputed values were based on regression models. Then a complete data set was generated for analysis. 
Multivariate normality is always assumed in maximum likelihood estimates which its violation leads to type 1 error problems and for the fact that chi square of fit index is sensitive to data deviation from the norm and significant outliers, multivariate normality test was conducted. Prior to this, the univariate normality was inspected and based on the values of skewness and kurtosis, all the individual distributions were normally distributed. This follows the recommendations of Kline (2011) which stipulated that no skewnes values exceed the absolute value of 3 and that of kurtosis should not exceed the absolute value of 10. In the case of multivariate normality the value of kurtosis is 6.265 showing a departure from normality since multivariate normality whose kurtosis value is greater than 5 deviated substantially from the norm. The multivariate non-normality was resolved when the bootstrapping procedure (Bollen-Stine bootstrap) available in Amos was conducted and the $p=.387$ indicating that the null hypothesis that the model is correct be accepted since the value is greater than 0.05 . Hence, the model is fit.

Table 1. Assessment of normality

\begin{tabular}{lrrrrrr}
\hline Variable & min & Max & skew & c.r. & kurtosis & c.r. \\
\hline Authoritarian & 4.000 & 16.000 & -.540 & -5.999 & .079 & .440 \\
Authoritative & 6.000 & 20.000 & -.735 & -8.169 & .917 & 5.098 \\
Permissiveness & 6.000 & 24.000 & .141 & 1.563 & -.407 & -2.259 \\
Academic self-efficacy & 8.000 & 40.000 & -1.112 & -12.363 & 1.640 & 9.112 \\
Test anxiety & 16.000 & 74.000 & .097 & 1.078 & .475 & 2.638 \\
Moral stance on examination & 19.000 & 76.000 & .698 & 7.760 & .366 & 2.035 \\
malpractice & & & & & 6.265 & 8.703 \\
Multivariate & & & & & & \\
\hline
\end{tabular}

The researchers also took into consideration linearity and multicollinearity. The linearity of the variables were determined by looking at the deviation for linearity for all the predictor variables and the dependent variables using SPSS. The range of deviation for linearity are: permissiveness and moral stance on examination malpractice, .08>.05, authoritarian and moral stance on examination malpractice, $.91>.05$, authoritative and moral stance on examination malpractice, .76>.05, self-efficacy and moral stance on exam malpractice, $.004<.05$, test anxiety and moral stance on examination malpractice, .09>.05. With the exception of selfefficacy on moral stance on examination malpractice, others are linearly related. Also multicollinearity test was conducted among the independent variables using SPSS to ascertain if they are highly corrected, the collinearity statistics showed that the VIF values range between 1.01-1.56 which fall below 10 indicating that predictor variables did not correlate highly. 


\section{Results}

\section{Preliminary analysis of correlation matrix, mean and standard deviation}

Table 2 showed the correlation matrix, mean and standard deviation of the variables of the study. Parenting styles had significant positive interrelationships among themselves $(p<.05)$, permissive parenting style had significant positive relation with low moral stance on examination malpractice $(p<.05)$. Authoritative parenting style had significant negative relationship with students' negative moral stance on examination malpractice $(p<.05)$ while academic self-efficacy had non-significant negative relationship with students' negative moral stance on examination malpractice ( $p>.05)$. Authoritarian parenting style had non-significant negative relationship with students' negative moral stance on examination malpractice ( $p>$.05). Permissive parenting had very low non-significant positive relationship with selfefficacy $(p>.05)$, authoritarian and authoritative parenting styles had significant positive relationship with academic self-efficacy $(p<.05)$. On the other hand, permissive parenting had moderate positive significant relationship with test anxiety, while authoritative and authoritarian parenting styles had low non-significant relationship with test anxiety. Academic selfefficacy, on the other hand, had low negative significant relationship with test anxiety. Mean statistic showed that the dominant parenting style among the students is the authoritative parenting, students had high mean score in academic self-efficacy, test anxiety and that almost half of the students have loose moral stance on examination malpractice.

Table 2. Correlation Matrix, Mean and Standard Deviation of the Variables

\begin{tabular}{lcccccc}
\hline & Permissive & $\begin{array}{c}\text { Authorita- } \\
\text { rian }\end{array}$ & $\begin{array}{c}\text { Authoritati- } \\
\text { ve }\end{array}$ & $\begin{array}{c}\text { Academic } \\
\text { self-efficacy }\end{array}$ & $\begin{array}{c}\text { Test an- } \\
\text { xiety }\end{array}$ & $\begin{array}{c}\text { Moral stance on } \\
\text { Exam Malpractice }\end{array}$ \\
\hline Permissive & 1 & & & & & \\
Authoritarian & $.44^{* *}$ & 1 & & & & \\
Authoritative & $.23^{* *}$ & $.30^{* *}$ & 1 & & & \\
Academic self-efficacy & .02 & $.14^{* *}$ & $.22^{* *}$ & 1 & & \\
Test anxiety & $.31^{* *}$ & $.07^{* *}$ & .05 & $-.10^{*}$ & 1 & \\
Moral stance on Exam & $.34^{* *}$ & -.07 & $-.14^{* *}$ & -.08 & $.31^{* *}$ & 1 \\
malpractice & & & & & & \\
Mean & 2.42 & 2.94 & 3.27 & 4.01 & 2.46 & 2.01 \\
SD & .62 & .64 & .51 & .79 & .59 & .69 \\
\hline
\end{tabular}

**. Correlation is significant at the 0.01 level (2-tailed).

*. Correlation is significant at the 0.05 level (2-tailed). 


\section{Measurement models}

Measurement models of the PAQ, TAI, SEQ-C and SMSEMQ were conducted using confirmatory factor analysis (CFA) (AMOS version 24) to determine the fits of the constructs among Nigerian students' sample before testing the proposed model. Factor loading of .40 was considered significant (Garson, 2010, as cited in Cabrera-Nguyen, 2010), and there was item reduction in the PAQ and in TAI. All the ítems in SEQ-C and SMSEMQ had factor loadings greater than .40 and were retained. Ítems retained in PAQ are 1, 2, 4, 7, 9, 10, 12, 17, 19, 21, 22, 23, 27, 28, and 30. The ítems in TAI that were retained were 4, 5, 6, 7, 8, 9, 11, 12, 13, 14, 15, 16, 17, 18, 19, 20 and those that were retained in the SMSEMQ were 1, 2, 3, 4, 5, 6, 10, 11, 12, 13, 17, 18, 19, $20,21,22,23,24$, and 25 .

For the fact that the SMSEMQ is a new instrument with little known about its psychometric properties, we conducted exploratory factor analysis (EFA) before the CFA. Principal axis factor analysis with varimax rotation was conducted to assess the underlying structure for the 25 items of the students' moral stance on examination malpractice scenarios questionnaire (SMSEMSQ). Missing data was checked, correlation matrix was examined and the interrelationships ranged between $>.20$ and $<.70$. The determinant was $<.00001$ and $>0$. The Kaiser-Meyer-Olkin (KMO) measure was .967 . The Bartlett test of sphericity was significant at 0.000 which is an indication that the variables are correlated highly enough to provide a reasonable basis for factor analysis as in this case. The Communalities table shows the Initial commonalities before rotation were above .30 except item 9. This was deleted and a rerun of the analysis was done with the remaining 24 items and all the values were more than .30 . The Total Variance Explained table shows how the variance is divided among the 24 possible factors and three factors have eigenvalues greater than 1.0.

This aligns itself to the 3 -cluster structure of the original instrument comprising the pre-examination malpractice scenario, during examination malpractice scenario and post examination malpractice scenario (Nwosu, et al, 2018). After rotation, the first factor accounted for $23.4 \%$ of the variance, the second factor accounted for $16.7 \%$, and the third factor accounted for $13.9 \%$. Table 3 shows the items and factor loadings for the rotated factors, with loadings less than .50 omitted to improve clarity. Factor 1 is for post-examination scenario, factor 2 is the pre-examination scenario while factor 3 is during examination malpractice scenario. However, we summed up all the items to arrive at students' moral stance on examination malpractice in our model. 
Table 3. Factor Loadings from Principal Axis Factor Analysis with Varimax Rotation for a Three-Factor Solution for the students' moral stance on examination malpractice scenarios questionnaire

\begin{tabular}{|c|c|c|c|c|c|}
\hline & & \multicolumn{3}{|c|}{ Factor } & \multirow[b]{2}{*}{ Commonality } \\
\hline & & 1 & 2 & 3 & \\
\hline SPE1 & I don't think it is wrong to see the question paper before the examination & & .554 & & .421 \\
\hline SPE2 & $\begin{array}{l}\text { If I have the opportunity to bribe a teacher to tell me the answers to ques- } \\
\text { tions to examination I will do that }\end{array}$ & & .746 & & .563 \\
\hline SPE3 & $\begin{array}{l}\text { I don't think it is wrong to prepare some material prior to entering the } \\
\text { exam hall }\end{array}$ & & .685 & & .511 \\
\hline SPE4 & It is not wrong to hire a mercenary to write exams for people. & & .663 & & .531 \\
\hline SPE5 & $\begin{array}{l}\text { I don't think it is wrong for somebody to contribute money as "kola nut" } \\
\text { for the invigilator }\end{array}$ & & .554 & & .430 \\
\hline SPE6 & $\begin{array}{l}\text { It is not wrong writing some formula in my hand/laps before entering the } \\
\text { hall, as reminder. }\end{array}$ & & .554 & & .475 \\
\hline SPE10 & It is not wrong to peep from my mate's work during examination & & & .511 & .457 \\
\hline SPE11 & It is not wrong to exchange ideas in examination hall with my colleagues & & & .601 & .366 \\
\hline SPE12 & It is not wrong to ask teachers for an answer in examination hall & & & .507 & .601 \\
\hline SPE13 & It is not wrong for one to copy answers written on the board by teachers & & & .590 & .541 \\
\hline SPE17 & $\begin{array}{l}\text { It is not wrong to cheat in exam malpractice when one is supported by } \\
\text { parents and school authorities }\end{array}$ & .588 & & & .596 \\
\hline SPE18 & $\begin{array}{l}\text { It is not wrong to indulge in exam malpractice when one is supported by } \\
\text { parents and school authorities }\end{array}$ & .646 & & & .635 \\
\hline SPE19 & $\begin{array}{l}\text { It is not wrong to send extra paper to mercenaries who will help you in } \\
\text { exam. }\end{array}$ & .651 & & & .599 \\
\hline SPE20 & $\begin{array}{l}\text { It is not wrong for one to give the invigilator money even after the time of } \\
\text { the exam has elapsed. }\end{array}$ & .636 & & & .552 \\
\hline SPE21 & $\begin{array}{l}\text { It is not wrong for one to go to the teachers to plead for scores when one } \\
\text { did not write well }\end{array}$ & .680 & & & .620 \\
\hline SPE22 & It is not wrong to put money in one's script to bribe the examiner & .700 & & & .584 \\
\hline SPE23 & $\begin{array}{l}\text { It is not wrong if my school should bribe the assessor that will mark our } \\
\text { script }\end{array}$ & .723 & & & .648 \\
\hline SPE24 & $\begin{array}{l}\text { It is not wrong to pay for special marking during marking of examination } \\
\text { scripts }\end{array}$ & .596 & & & .431 \\
\hline SPE25 & It is not wrong to pay for another person's results to be given to me & .624 & & & .474 \\
\hline
\end{tabular}

In intepreting CFA, we adopted fit índices in addition with the conventional chisquare test usually impacted by a large sample size (Browne \& Cudeck, 1993). The fit índices and the range of the loadings for each instrument are shown in table 4. PAQ and TAI showed marginal model-to-data fit. Though these model fit índices achieved marginal fits, for the fact that they improved significantly after deletion of ítems that loaded below .40, they were used for further analysis. 
Table 4. CFA Model Fit of the Instrument and Loadings

\begin{tabular}{lcccccc}
\hline Measurements & $X^{2}$ & Df & RMSEA & GFI & CFI & $\begin{array}{c}\text { Sumarized range } \\
\text { of loadings }\end{array}$ \\
\hline $\begin{array}{l}\text { Parenting styles (Three- } \\
\text { dimensional) }\end{array}$ & $290.1^{* *}$ & 87 & .056 & .947 & .861 & $.40-.62$ \\
$\begin{array}{l}\text { Test anxiety (unidimensio- } \\
\text { nal) }\end{array}$ & $502.1^{* *}$ & 104 & .072 & .916 & .882 & $.41-66$ \\
$\begin{array}{l}\text { Academic self-efficacy (uni- } \\
\text { dimensional) }\end{array}$ & $129.1^{* *}$ & 20 & .086 & .953 & .928 & $.43-73$ \\
$\begin{array}{l}\text { Moral Stance on examination } \\
\text { malpractice (three- }\end{array}$ & $514.3^{* *}$ & 149 & .057 & .929 & .954 & $.58-.83$ \\
dimensional)
\end{tabular}

\section{Hypothesized structural model fit indices}

The model fit was assessed using the goodness-of-Fit index (GFI), the comparative fit index (CFI), the incremental fit index (IFI), the Trucker Lewis Index (TLI), the normed fit index (NFI), root mean square error of approximation (RMSEA) and Chi-square and degree of freedom. Results show that Goodness-of-Fit Index (GFI) has a value above 1.000. The TLI, CFI and NFI values of 1.009, 1.000 and .999 respectively indicated that the hypothesized model represented an adequate fit to the data (values above 0.90 being indicative of good fit). Similarly, the proposed model has a value of 0.000 for its Root Mean Square Error of the Approximation (RMSEA) (which should be less than 0.08), the ratio of Chi-square to degrees of freedom is within the recommended fit of less than 5 . Thus, all the tests and measures, indicate that the model has a good fit.

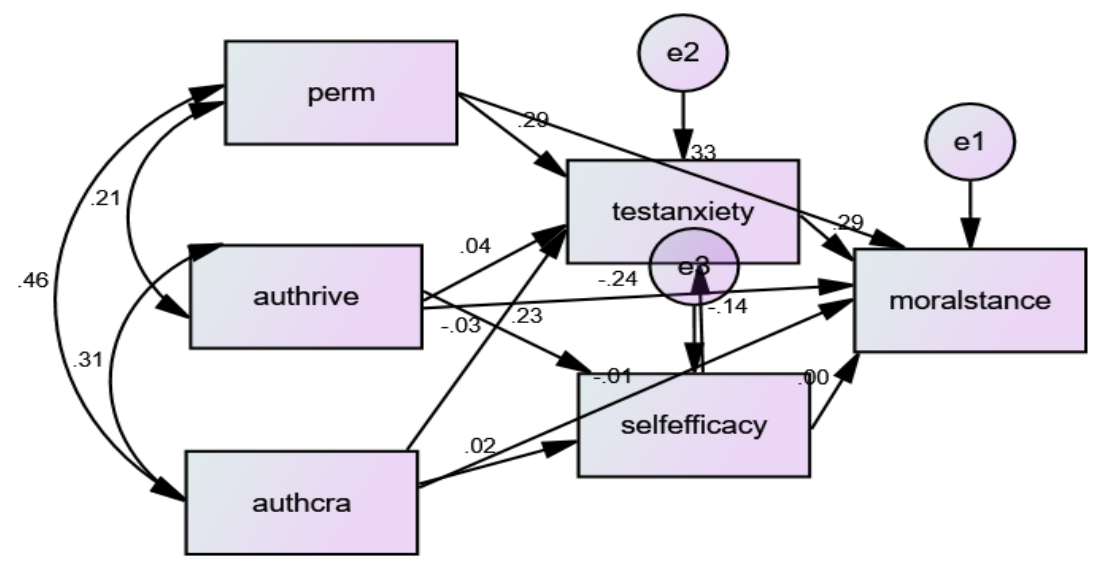

Figure 2. Empirical model fit of the variables

Note: perm=permissive parenting, authrive=authoritative parenting, authcra = Authoritarian parenting, Selfefficacy $=$ academic self-efficacy, moral stance $=$ moral stance on examination malpractice 


\section{Direct Impacts of Exogenous variables on Endogenuos Variables}

Before the full structural model was determined, we hypothezied that parenting styles would have significant effects on students' moral stance on examination malpractice. Analysis shows the direct effects of parenting styles on students' moral stance on examination malpractice indicating that permisive parenting $(\beta=.298, P<0.05)$ and authoritative parenting $(\beta$ $=-.242, P<0.05)$ styles had significant effects on students' moral stance on examination malpractice while authoritarian parenting style $(\beta=.030, P>0.05)$ had no significant effect on moral stance on examination malpractice.

Table 5 showed the direct paths of the full model. Authoritative parenting significantly predicted academic self-efficacy $(p<0.05)$ while authoritarian parenting style did not $(p>0.05)$. Only permissive parenting significantly and positively predicted test anxiety $(p<0.05)$ while authoritative and authoritarian parenting styles did not significantly predict test anxiety $(p>0.05)$. Academic self-efficacy was a significant negative predictor of test anxiety $(p<0.05)$. Predictors of students' moral stance on examination malpractice are permissive parenting, authoritative parenting and test anxiety $(p<0.05)$.

Table 5. Regression Weights, Probability Values of the Variables of the Model

\begin{tabular}{|c|c|c|c|c|}
\hline Parameter & & & Estimate & $P$ \\
\hline Academic self-efficacy & $<---$ & Authoritarian & .020 & .594 \\
\hline Academic self-efficacy & $<---$ & Authoritative & .233 & .005 \\
\hline Test anxiety & $<---$ & Permissiveness & .289 & .003 \\
\hline Test anxiety & $<---$ & Authoritative & .038 & .357 \\
\hline Test anxiety & $<---$ & Authoritarian & -.033 & .442 \\
\hline Test anxiety & $<---$ & Academic self-efficacy & -.143 & .004 \\
\hline $\begin{array}{l}\text { Moral stance on exam malprac- } \\
\text { tice }\end{array}$ & $<---$ & Permissiveness & .327 & .003 \\
\hline $\begin{array}{l}\text { Moral stance on exam malprac- } \\
\text { tice }\end{array}$ & $<---$ & Authoritative & -.241 & .005 \\
\hline $\begin{array}{l}\text { Moral stance on exam malprac- } \\
\text { tice }\end{array}$ & $<---$ & Authoritarian & -.010 & .713 \\
\hline $\begin{array}{l}\text { Moral stance on exam malprac- } \\
\text { tice }\end{array}$ & $<---$ & Academic self-efficacy & -.001 & .932 \\
\hline $\begin{array}{l}\text { Moral stance on exam malprac- } \\
\text { tice }\end{array}$ & $<---$ & Test anxiety & .287 & .002 \\
\hline
\end{tabular}


Table 6 shows the total, direct, and indirect effects of the variables on the endogenous (dependent) variable (students' moral stance on examination malpractice). Authoritative parenting style has a negative significant total and direct effects $(p<0.05)$ on students' moral stance on examination malpractice. Authoritarian parenting style has no significant total and direct effects on students' moral stance on examination malpractice $(p>0.05)$. Permissive parenting style has positive significant total and direct effects $(p<0.05)$ on students' moral stance on examination malpractice. On the issue of mediation effect, only permisive parenting through test anxiety was considered in this model. The decisión is infromed by Baron and Kenny (1986) conditions for testing mediation hypothesis which stated that: a) independent variables must significantly predict the dependent; b) the independent variable must significantly predict the mediator variable; and c) the moderator variable must predict the dependent variable. Mediation analysis was ignored in cases that failed these conditions. We found a positive, significant and partial mediating effect of permissive parenting style on students' amoral stance in examination malpractice through test anxiety $(\beta=.083, \mathrm{p}<0.05)$ based on 1000 bootstrap sample at 95 bias-corrected confidence interval to determine its level of significance.

Table 6. Standardized Total Effects, Direct Effects and Indirect Effects of the Variables in the Model

\begin{tabular}{lccc}
\hline Variables & Total effect & Direct Effect & Indirect Effect \\
\hline Authoritative on moral stance on exam malpractice & $-.240 * *$ & $-.241 * *$ & .001 \\
Authoritarian on moral stance on exam malpractice & -.021 & -.010 & -.010 \\
Permissive on moral stance on exam malpractice & $.410 * *$ & $.327 * *$ & $.083 *$ \\
\hline
\end{tabular}

\section{Discussion and conclusion}

This path analysis study attempted to provide an empirical model to explain the predictive nature of parenting styles, test anxiety, academic self-efficacy on adolescents' moral stance on examination malpractice scenarios. Data collected fit the conceptualized model indicating the fact that understanding the way students view examination malpractice demands 
an examination of their beliefs, the way they were brought up and psychological variables related to taking examinations/tests. This is very pertinent given that when this is understood, evidenced-based intervention programmes could be mounted for them.

Descriptive statistics showed that the dominant parenting style among the students is the authoritative parenting, students had high mean score in academic self-efficacy, test anxiety and that a good number of the students have loose moral stance on examination malpractice. Authoritative parenting being predominant among the respondents concurs with research studies in the Nigerian context which has shown that most Nigerian parents adopt authoritative parenting style with a mix of authoritarian style (Akinsola, 2013). The patriarchal nature of the Nigerian society suggests the firmness of parental authority and sometimes parenting styles swing the pendulum of authoritarianism. Here the child is expected to follow rules of significant persons without questioning. Other studies outside Nigeria have shown that predominant parenting style adopted by parents is the authoritative parenting style (Abesha, 2012; Butnaru, 2016; Rosli, 2012). Important, also, is the finding that students had higher mean scores in academic self-efficacy, which shows that they perceived themselves to have abilities that could help them succeed academically. Students also have higher mean scores in test anxiety signaling the fact that they may be test anxious. The fact that they perceived themselves as self-efficacious in their academics contradicted the finding that they are also test anxious. However, recent studies have found that Nigerian students have high test anxiety which has been attributed to the high premium placed on certification in Nigeria (Nwamuo \& Ihekwaba, 2014; Nwosu et al., 2017) this can erode their high academic self-efficacy especially when they are faced with evaluative situations bearing in mind the emphasis on performance rather than mastery. On their moral stance on examination malpractice, finding further indicated that a good number of students have loose moral stance on examination malpractice and see nothing wrong in engaging in examination malpractice. This is in line with the findings of Nwosu et al. (2018) in which a good number of students said they see nothing wrong breaking the rules of examination. Moreover, Nigerian secondary school students in the study conducted by Nwosu et al. (2017) scored high in cheating tendencies.

Permissive parenting style had significant positive relationship with low moral stance on examination malpractice. Authoritative parenting style had significant negative relationship with students' low moral stance on examination malpractice while academic self efficacy has non-significant relationship with students' low moral stance on examination malpractice. 
The positive relationship existing between permissive parenting and low moral stance on examination malpractice could be accounted for by the fact that there is little rule in parental regulation of the conduct of the child. The child may be given almost limitless freedom in seeing to his/her own affair. This implies that the more permissive parenting is adopted in bring up a child, the more the child is likely to see nothing wrong in acts that violate examination ethics. This finding is also in line with similar studies that have linked examination malpractice to permissive parenting (Opiyo et al., 2018). Opiyo et al. (2018) found very strong relationship between permissiveness and examination misconduct. Although, in the study conducted by Onyekuru et al. (2017), permissive parenting had negative significant relationship with attitude to examination malpractice, neglectful parenting had positive relationship with attitude to examination malpractice. This implies that different parenting typologies could lead to different findings. In our study, it is not only that the relationship between low moral stance on examination malpractice and permissive parenting was established, permissive parenting had both direct and indirect positive effects on low moral stance on examination malpractice among Nigerian secondary school students. The impact of permissive parenting on students' moral stance on examination malpractice was partially mediated by test anxiety. What this means in essence is that permissive parenting style could cause high test anxiety, and high test anxiety could lead to amoral stance on examination malpractice among adolescent students. The moral lense from which the students viewed examination malpractice is in part dependent on their level of test anxiety. Studies have shown how test anxiety impacts on students' tendency to indulge in examination malpractice (Nwosu et al., 2017) and their attitude to examination malpractice (Ossai, 2011). The fact that the indirect effect was still significant indicates the significant role of permissive parenting in the amoral views of students on examination malpractice. Researchers have shown that permissiveness is strongly and positively linked to tendency to induge in examination malpractice (Opiyo et al., 2018). This tendency is an outcome of the way they judge participation in examination malpractice. Permissive parenting is the highest significant predictor in our model signifying that lax parenting could lead to low moral stance on examination malpractice. In this light, Johnson (2016) had noted that permissive parenting style fosters amoral behaviours among adolescents.

Equally important in our finding is the fact that authoritative and authoritarian parenting styles had negative with relationships with students' examination malpractice moral stance with authoritaive parent having significant relationship with examination malpractice 
stance. The 'rules of engagement' in these parenting styles would have impacted on the way students viewed examination malpractice. In the authoritative parenting style, there is opportunity for the parents and children to dialogue and the consequences of their actions placed on the table. Adolescents at this point could be well informed of the moral consequences of engaging in examination malpractices. Johnson (2016) is of the view that moral belief systems of the parents could be transferred to their children. In the authoritarian parenting style, 'don't do this' insistence could also impact on adolescents' moral stance on examination malpractice. However, while authoritative parenting style significantly predicted adolescents' moral stance on examination malpractice, authoritative parenting did not. However indirect effects of authoritarian and authoritative parenting styles on adolescents' examination malpractice moral stance were not detremined here given that requisite conditions were not met.

Looking at the relationships existing among parenting styles, academic self-efficacy and test anxiety, finding showed that permissive parenting had very low non-significant positive relationship with self-efficacy while authoritarian and authoritative parenting styles had significant positive relationship with academic self-efficacy. This is similar to other studies that have demonstrated significant positive relationship between authoritative parenting and students' self-efficacy (Abesha, 2012; Tam, Chong, Kadirvelu, \& Khoo, 2012) while permissive parenting is associated with either low self-efficacy or negative relationship with selfefficacy and researchers have linked this to the lax parenting supervision in permissive parenting (Tam et al., 2012).

On the other hand, permissive parenting had moderate positive significant relationship with test anxiety, while authoritative and authoritarian parenting styles had low significant relationship with test anxiety. Even though literature shows that not much empirical work work has been done on relationship between parenting styles and test anxiety, available works have associated poor parenting styles with general and context/situation specific anxiety (e.g., test anxiety) (Butnaru, 2016) while more democratic parenting styles such as authoritative parenting style have been found to have significant negative relationship with test anxiety (Nwufo, Onyishi, Ubom, Akinola, \& Chukwuorji, 2017). This relationship could be that extremities in behavior control by parents could result in behavioural problems. However, this finding contradicted, in part, the findings of Nwosu, Nwanguma and Onyebuchi (2016) in which parenting styles had no significant relationship with test anxiety. We found that it was 
only permissive parenting style that had significant relationship with students' moral stance on examination malpractice.

Academic self-efficacy, on the other hand, had low negative significant relationship with test anxiety. What this implies is that the more adolescents perceive themselves as academically efficacious, the less they are likely to exhibit test anxiety. This is in line with similar studies that have correlated self-efficacy with anxiety (Asayesh, Hosseini, Sharififard, \& Kharameh, 2018; Tahmassian \& Moghadam, 2011). The fact that one feels able to perform a task is likely to reduce the anxiety associated with such a task.

The study is limited by the fact that it adopted only a quantitative research design. Adoption of a mixed method where the findings could be triangulated will produce more robust data. The use of questionnaire alone is not likely to give respondents the opportunity to express how they feel. More so, there were missing values in the data collected even though these were handled using regression imputation available in AMOS. Apart from this, the parental questionnaire was not administered in such a way that the mothers' and the fathers' parenting styles could be unpacked though the patriarchal nature of the Nigerian society seem to place the mother under the father. However, this could be taken into consideration in subsequent studies. Also, PAQ, TAI and SEQ-C showed almost minimal fits among this population indicating that further studies may require development of indigenous instruments for these constructs.

Despite the aforementioned limitations, our study has merit given that it has helped in providing empirical pathways that explain the factors that impact adolescents' moral stance on examination malpractice. Insightful is our finding that deficient parenting styles have positive significant direct and indirect impacts on adolescents' amoral stance on examination malpractice. Permissive parenting style is the most significant predictor of adolescents' moral stance on examination malpractice followed by test anxiety. This could be a pointer to the fact that efforts to curb examination malpractice in Nigeria should begin with reorientation and interventions on how parents bring up their children. School psychologists and counsellors should organize intervention programmes that will help reduce test anxiety and improve on students' academic self-efficacy. 


\section{References}

Abesha, A. Y. (2012). Effects of parenting styles, academic self-efficacy, and achievement motivation on the academic achievement of university students in Ethiopia (Doctoral dissertation, Edith Cowan University, Australia). Retrieved from: https://ro.ecu.edu.au/cgi/viewcontent.cgi?article $=1461 \&$ context $=$ theses .

Ajiboye, O.E., Atere, A.A., \& Olufunmi, A.N. (n.d). Changing Patterns of Child Rearing Practice In Badagry Area of Lagos State: Implication for Delinquent Behaviour. European Scientific Journal, 8, (5): 28-54

Akinsola, E. F. (2013). Cultural variations in parenting styles in the majority world: Evideces from Nigeria and Cameroon. http://dx.doi.org/10.5772/57003.

Alhassan, A. B. \& Anya, C. A. (2017). Forms and consequences of examination malpractices' in Nigeria's schools and universities: What should the stakeholders do? Intern tional Journal of Education, Training and Learning, 1 (1), 9-21. doi: 10.33094/6.2018.11.9.2

Amos, P.M. (2013). Parenting and Culture - Evidence from Some African Communities. Available at: http://dx.doi.org/10.5772/56967

Animasahun, R. A. \& Ogunniran, J. O. (2014). Correlates of examination malpractice among secondary school students in Oyo State, Nigeria. International Journal of Educational Administration and Policy Studies, 6(9), 181-189. doi: 10.5897/IJEAPS2014.0375.

Asayesh, H., Hosseini, M. A., Sharififard, F., \& Kharameh, Z. T. (2018). The relationship between self-efficacy and test anxiety among the paramedical students of Qom University of Medical Sciences. Journal of Advances in Medical Education (JAMED), 1(3), 8-12. Retrieved from: https://www.semanticscholar.org/paper/The-relationship between-self-efficacy-and-test-the-Asayesh Hoseini/ 3dbf9a5b4eaee5e4ea5fadd70e10fd676e50fc7f

Bacus, M. P. (2014). Parenting styles, self-concept and attitude of students: A causal model on academic performance. International Conference on Economics, Social Sciences and Languages (ICESL'14), May 14-15, Singapore. Retrieved from: https://icehm.org/upload/1162ED0514054.pdf 
Barni, D. Ranieri, S. Scabini, E. S., \& Rosenati, R. (2011). Value transmission in the family: Do adolescents accept the values their parents want to transmit? Journal of Moral Education,40(1), 105-121. doi: 1080/03057240.2011.553797

Baron, R. M., \& Kenny, D. A. (1986). The moderator-mediator variable distinction in social psychological research: Conceptual, strategic, and statistical considerations. Journal of Personality and Social Psychology, 51, 1173-1182. doi:10.1037/0022-3514.51.6.1173

Butnaru, S. (2016). Perceived parenting styles and school anxiety in preadolescents. CBU International Conference on Innovations in Science and Education, March 23-25, 2016, Prague, Czech Republic. doi: http://dx.doi.org/10.12955/cbup.v4.801

Cabrera-Nguyen, P. (2010). Author guidelines for reporting scale development and validation results in the Journal of the Society for Social Work and Research. Journal of the Society for Social Work and Research, 1(2), 99-103. DOI: 10.5243/jsswr.2010.8

Cameron, M., Cramer, K. M. \& Manning, D. (2018). Relating parenting styles to adult emotional intelligence: A retrospective study. Athens Journal of Social Sciences, XY (1), 113. Retrieved from: https://www.athensjournals.gr/social/2018-2243-AJSS.pdf

Cornelius-Ukpepi, B. U., Ndifon, R. A., \& Enukoha, I. E. (2012). Correlates of examination malpractice and academic performance of primary school students in Cross River State, Nigeria. American Journal of Social Issues \& Humanities, 2(6), 398-405. Retrieved from:_citeseerx.ist.psu.edu > viewdoc > download $>$ type $=p d f$

Darling, N. \& Steinberg, L. (1993). Parenting style as context: An integrative model. Psychlogical Bulletin, $113 \quad$ (3), 487-496. $\quad$ http://pepparent.org/wpcontent/uploads/2014/01/Parenting-style-as-context-An-integrative-model-1993.pdf

Exam Ethics Marshals International (2019). Report and recommendations on the 23rd EEMI conference and awards at Abuja. Retrieved from: http://www.examethicsmarshals.org/reports-and-recommendations-on-the-23rd-eemic conference-and-awards-held-at-abuja

Hollequ, K. L. (1982). Cheating behaviors of college students (Doctoral Dissertation, Montna State University, United States).

Ifijeh, G., Michael-Onuoha, H., Ilogho, J., \& Osinulu, F. (2015). Emergence of hi-tec examination malpractices in Nigeria: Issues and implications. International Journal of 
Education and Research, 3(3), 113-122. Retrieved from: https://www.ijern.com >jour$\underline{\text { nal }>2015>\text { March-2015 }}$

Johnson SA (2016) Parenting styles and raising delinquent children: Responsibility of parents in encouraging violent behavior. Forensic Research and Criminology International Journal, 3(1), 00081. doi:10.15406/frcij.2016.03.00081

Jurdy, R., Hage, H. S., \& Chow, H. P. H. (2011). Academic dishonesty in the Canadian class -room: Behaviours of a sample of university students. Canadian Journal of Higher Education, 41(3), 1-35. Retrieved from: journals.sfu.ca > cjhe > index.php > cjhe > article > view

Kirikkanat, B. \& Soyer, M. K. (2017). A path analysis model pertinent to undergraduates' academic success: Examining academic confidence, psychological capital and academic coping factors. European Journal of Educational Research, 7(1), 133 - 150. Doi: $\underline{10.12973 / \text { eu-jer.7.1.133 }}$

Knafo, A. \& Schwartz, S. H. (2003). Parenting and adolescents' accuracy in perceiving parenting values. Child Development, 74(2), 595-611. Retrieved from https://www.jstor.org/stable/3696333

Kuppens, S. \& Ceulemans, E. (2018). Parenting styles: A closer look at a well-known concept. Journal of Child and Family Studies. https://doi.org/10.1007/s10826-018-1242-x

Naliaka, P. Odera, P. \& Poipoi, M. (2015). Perceived psycho-social and school factors contributing to malpractices in internal examinations among secondary school students in Kakamega Central Sub-County: Implications for counselling. International Journal of Psychology and Counselling, 7(2), 18-23. Retrieved from: academicjournals.org/journal/IJPC/article-full-text pdf/5892EA050942

Nora, W. L. Y. \& Zhang, K. C. (2010). Motives of cheating among secondary students: The role of self-efficacy and peer influence. Asian Pacific Education Review, 11, 573-584. doi: 10.1007/s12564-010-9104-2

Nwosu, K. C., Nwanguma, V. C. \& Onyebuchi, G. C. (2016). Parenting styles, test anxiety, and self-efficacy of secondary school students in Nigeria: Lessons from Nigerian sociocultural context. Education Research Journal, 6(2), 32 - 41. Retrieved from: http://resjournals.com/journals/educational-research-journal.html 
Nwosu, K. C., Nwasor, V. C. \& Nezieanya, C. A. (2018). Moral judgments of Nigerian se condary school students on examination malpractices: The pre-during-and-post examination scenarios. Journal Plus Education, 19(1), 116-130. Retrieved from: http://www.uav.ro/jour/index.php/jpe

Nwosu, K. C., Odo, C. \& Obioha, O. A. (2017). Relationship between Nigerian secondary school students' test anxiety and their tendency to indulge in examination malpractice. Journal of Nigerian Academy of Education, 13(2), 52-62.

Ofodile, M. C., Odiato, O. O., Adenugba, A. A., \& Edun, T. (2019). Self-efficacy, test of anxiety and examination malpractices in Ogun state. The Journal of Positive Psychology and Counselling, 3(1), 134-145. Retrieved from: https://www.ppacjournals.org/download.php?filename=JPPCOFODILEpg134

Ojo, O. D. \& Olumuyiwa, F. A. (2011). Parental influence on wards in escalation of examination misconduct in Nigeria. European Journal of Social Sciences, 19(2), 297-307. Retrieved from: https://core.ac.uk/download/pdf/16435993.pdf

Okorodudu, G. N. (2012). Relationship between parental motivation, self-efficacy and examination dishonesty among secondary school students in Delta State. International Journa of Psychological Studies, 4(4), 80-89. URL:http://dx.doi.org/10.5539/ijps.v4n4p80.

Onyekuru, B. U. \& Kabari, B. M. (2017). Parenting styles as correlates of students' attitude towards examination malpractices in Obio/Akpor Local Government Area of RiversState: Implications for counselling. European Journal of Educational and Development Psychology, 5(2), 1-11. Retrieved from: http://www.eajournals.org/wp co tent/uploads/Parenting-Styles-as-Correlates-of-Students\%E2\%80\%99-Attitude $\mathrm{t}$ wards-Examination Malpractices-in-Obio-Akpor-Local-Government-Area-of-Rivers State-1.pdf

Opiyo, P. O, Aloka, P. J. O., Raburu, P. A., \& Aomo, J. A. (2018). Relationship between permissive parenting style and examination cheating tendencies among Kenya secondary school students. Mediterranean Journal of Social Sciences, 9(3), 225-231. doi: 10.2478/mjss-2018-0064.

Ossai, M. C. (2011). Guidance and counselling implications of examination anxiety as a predictor of students' attitude towards examination malpractices. Proceedings of the 2011 International Conference on Teaching, Learning and Change. Retrieved from: www.hrmars.com > admin > pics 
Paul, S. O., Wada E., Audu, E. \& Omisore, O. (2013). Examination malpractice: Challenges to human resource development in Nigeria. International Journal of Capacity Building in Education and Management, 2(1), 91-101. Retrieved from: https://www.academia.edu > Examination_Malpractice_Challenges_to_Huma...

Petters, J. S. \& Okon, M. O. (2014). Students' perception of causes and effects of examination malpractice in the Nigerian educational system: A way forward for quality education. Procedia-Social and Behavioural Sciences, 114, 125-129. DOI:10.1016/j.sbspro.2013.12.671

Rana, R. A. \& Mahmood, N. (2010). The relationship between test anxiety and academic achievement. Bulletin of Education and Research, 32 (2), 63- 74. Retrieved from: https://pdfs.semanticscholar.org > ...

Rosli, N. A., (2012). Effect of parenting styles on children's emotional and behavioral problems among different ethnicities of Muslim Children in the U.S. (DoctoralDissertations, Marquette University). Retrieved fromhttp://epublications.marquette.edu/dissertations_mu/376.

Suleman, Q., Gul, R., Ambrin, S., \& Kamran, F. (2015). Factors contributing to examination malpractices at secondary school level in Kohat Division, Pakistan. Journal of mEducation and learning, 9(2), 165-182. Retrieved from:https://pdfs.semanticscholar.org >

Tahmassian, K., Moghadam, N. J. (2011). Relationship between self-efficacy and symptoms of anxiety, depression, worry and social avoidance in a normal sample of students. Iran Journal of Psychiatry and Behavioural Science, 5(2), 9-18. Retrieved from: https://www.ncbi.nlm.nih.gov/pmc/articles/PMC3939966/

Tam, C-L., Chong, A., Kadirvelu, A. \& Khoo, Y-T. (2012). Parenting styles and self-efficacy of adolescents: Malaysian scenario. Global Journal of Human Social Science, 12(14), 18-25. Retrieved from: https://globaljournals.org/GJHSS_Volume12/3

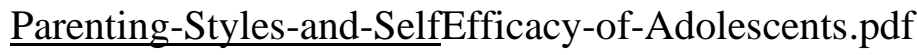

Tappan, M. B. (2005). Mediated moralities: Sociocultural approaches to moral development. Retrieved from https://core.ac.uk > download > pdf

Wowra, S. A. (2007). Moral identities, social anxiety, and academic dishonesty among American college students. Ethics and Behaviour, 17(3), 303321.https://doi.org/10.1080/10508420701519312 
Wright, J. D. \& Wright, S. R. (1976). Social class and parental values for children: A partial replication and extension of the Kohn thesis. American Sociological Review, 41, 527537.Retrieved from: https://www.scirp.org > reference > ReferencesPapers

Received: 04-01-2020

Accepted: 02-06-2020 